\title{
Inferior alveolar nerve repositioning and securing in conjunction with dental implant placement: a technical note
}

\author{
George Deryabin ${ }^{1 *}$ (D) and Simonas Grybauskas ${ }^{2}$
}

Keywords: Inferior alveolar nerve transposition, Vestibuloplasty, Dental implants, Titanium screws

Loss of teeth in the posterior mandible leads to progressive alveolar bone resorption, diminishing the amount of attached and unattached mucosa and superficial location of the inferior alveolar nerve (IAN) [1]. Applying dental implants in cases with these bone defects may require multiple surgeries, including vestibuloplasty and soft tissue grafting during the final treatment stages [2]. IAN transposition or lateralisation in combination with dental implant placement is a seldom-used treatment modality due to its complexity and potential IAN damage. However, these techniques could be successfully utilised in cases where there is less than $10 \mathrm{~mm}$ bone height above the canal and the quality of cancellous bone is poor [3]. There are insufficient data on how the IAN should be handled and secured to minimise its long-term morbidity [4]. In certain IAN repositioning cases, it is left covered with only a thin layer of bone or soft tissues. Therefore, vestibuloplasty at the time of implant uncovering could pose a real challenge to salvaging the IAN during mucosal separation.

The purpose of this article was to demonstrate a technique utilising titanium screws as IAN markers during its repositioning. These screws serve as land- marks that allow a clinician to easily locate the IAN during vestibuloplasty or placement of healing abutments.

The operation is performed under a combination of local anaesthesia with IV sedation. A crestal incision is made in the keratinised gingiva of the edentulous area. It is initiated in the retromolar region at the mucogingival junction and carried out toward the distal aspect of the most posterior tooth. A full-thickness flap is elevated, exposing the alveolar crest and lateral body of the mandible to the mental foramen. A full corticotomy is performed with a piezoelectric saw creating a rectangular bony window lateral to the inferior alveolar canal according to the IAN pathway that was determined by preoperative computed tomography scan (Figs. 1, 2, 3). The bony window is removed, exposing the neurovascular bundle within the inferior alveolar canal. The neurovascular bundle is mobilised and retracted laterally while implants are installed (Fig. 4). In cases of nerve transposition, the osteotomy window is extended anteriorly to expose the mental foramen and incisive branch. Then, the incisive branch is transected, and the IAN is freed from the canal and displaced laterally.

\footnotetext{
* Correspondence: georgederyabin@gmail.com

${ }^{1}$ Chicago, USA

Full list of author information is available at the end of the article
}

\section{Springer Open}

(ㅇ The Author(s). 2020 Open Access This article is licensed under a Creative Commons Attribution 4.0 International License, which permits use, sharing, adaptation, distribution and reproduction in any medium or format, as long as you give appropriate credit to the original author(s) and the source, provide a link to the Creative Commons licence, and indicate if changes were made. The images or other third party material in this article are included in the article's Creative Commons licence, unless indicated otherwise in a credit line to the material. If material is not included in the article's Creative Commons licence and your intended use is not permitted by statutory regulation or exceeds the permitted use, you will need to obtain permission directly from the copyright holder. To view a copy of this licence, visit http://creativecommons.org/licenses/by/4.0/. 


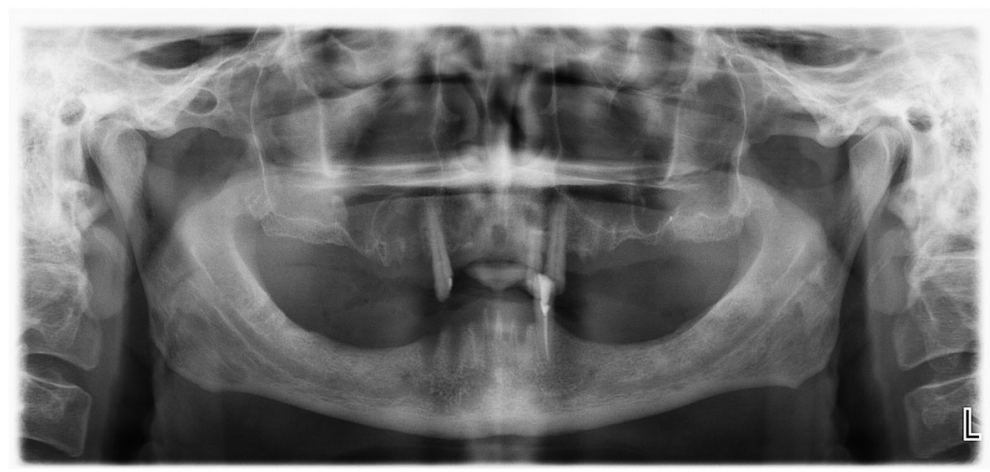

Fig. 1 A panoramic radiography before surgery

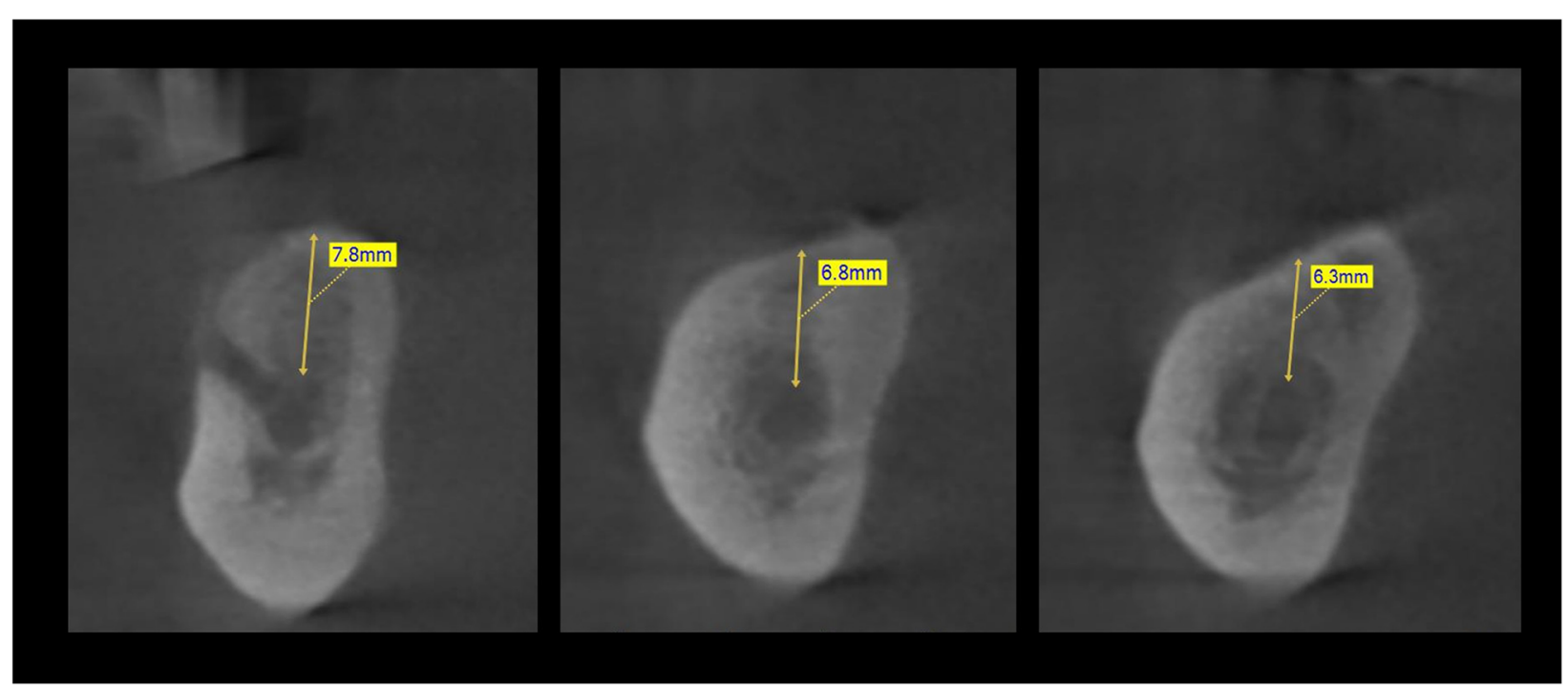

Fig. 2 A CT scan before surgery 


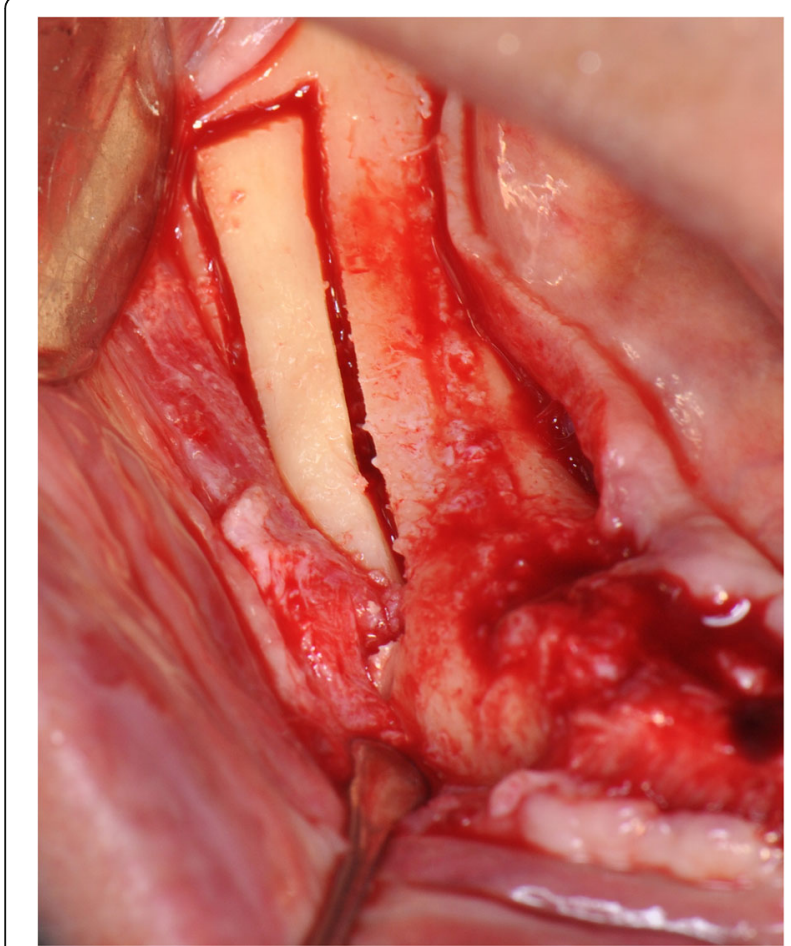

Fig. 3 A full corticotomy is performed creating a rectangular bony window lateral to the inferior alveolar canal

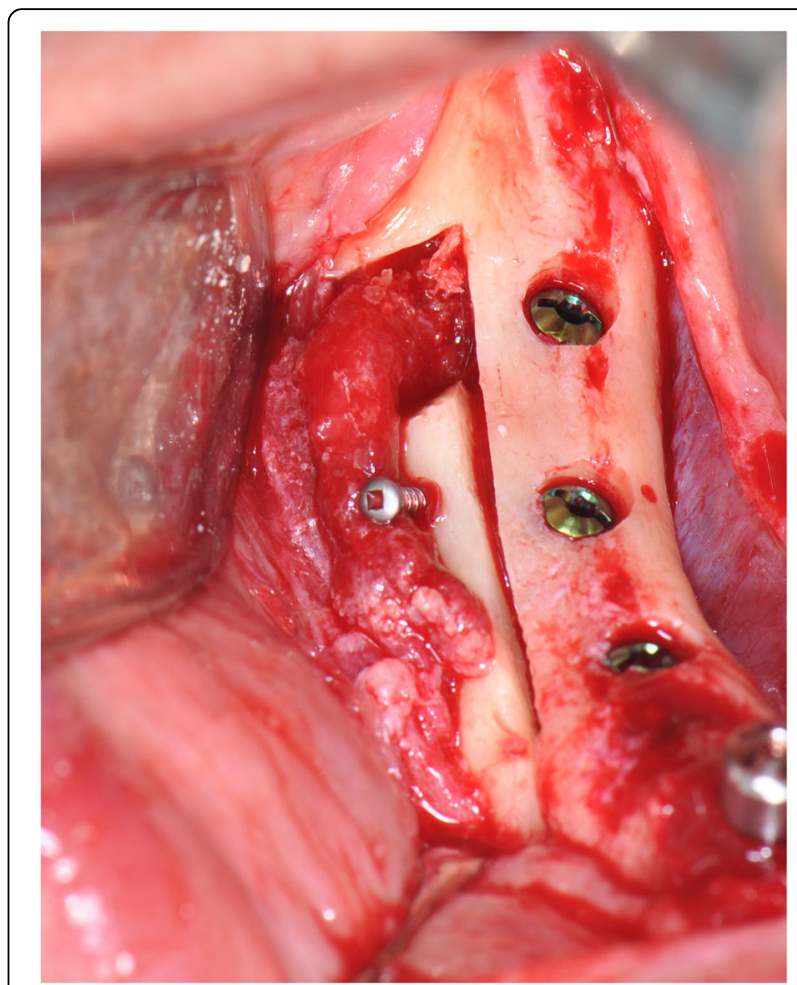

Fig. 5 A titanium mini-screw is placed halfway on the lateral side of the mandible at the upper osteotomy line

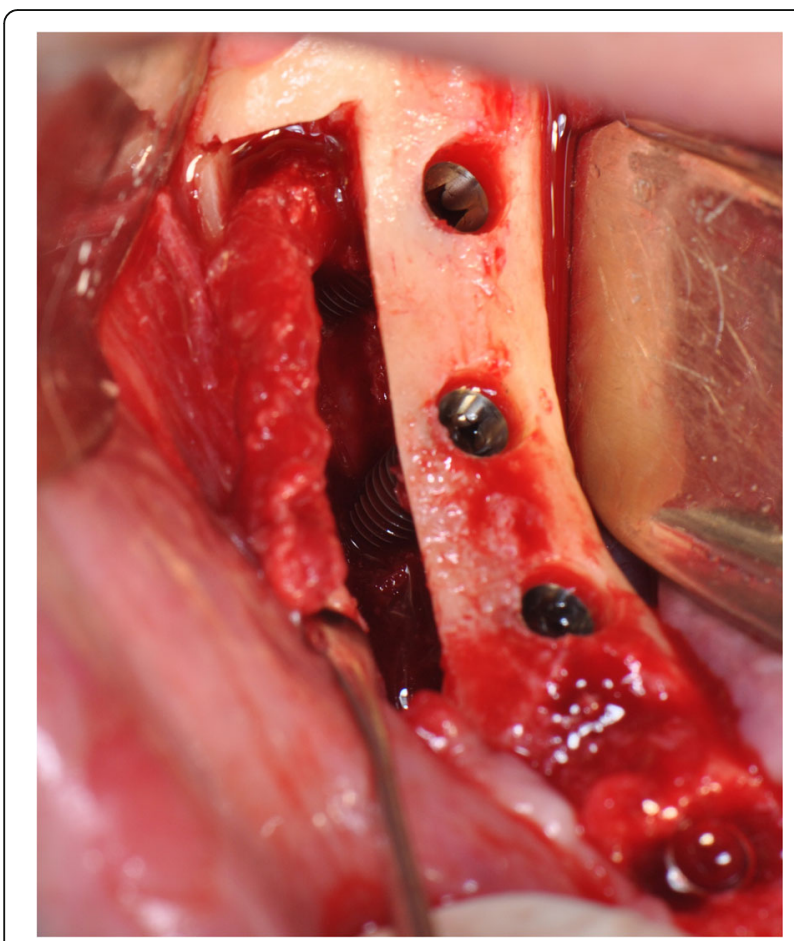

Fig. 4 The neurovascular bundle is mobilised and retracted laterally while the implants are installed 


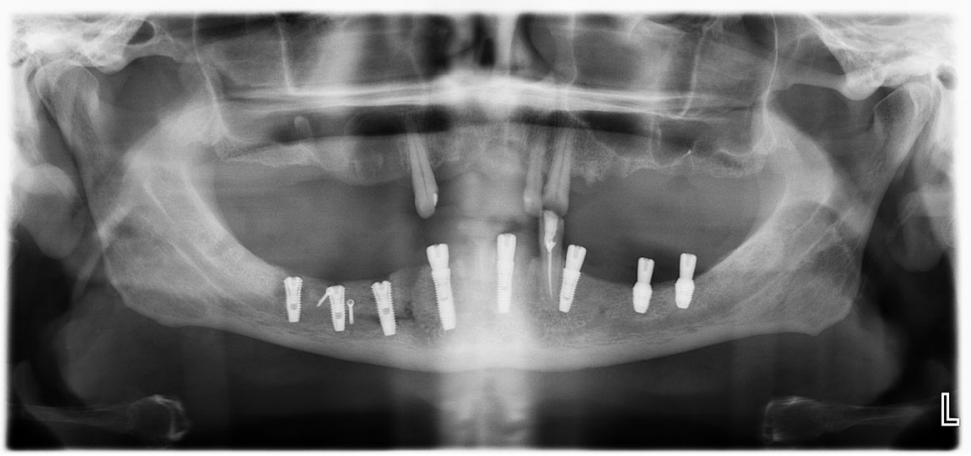

Fig. 6 A panoramic radiography after IAN transposition and implant placement

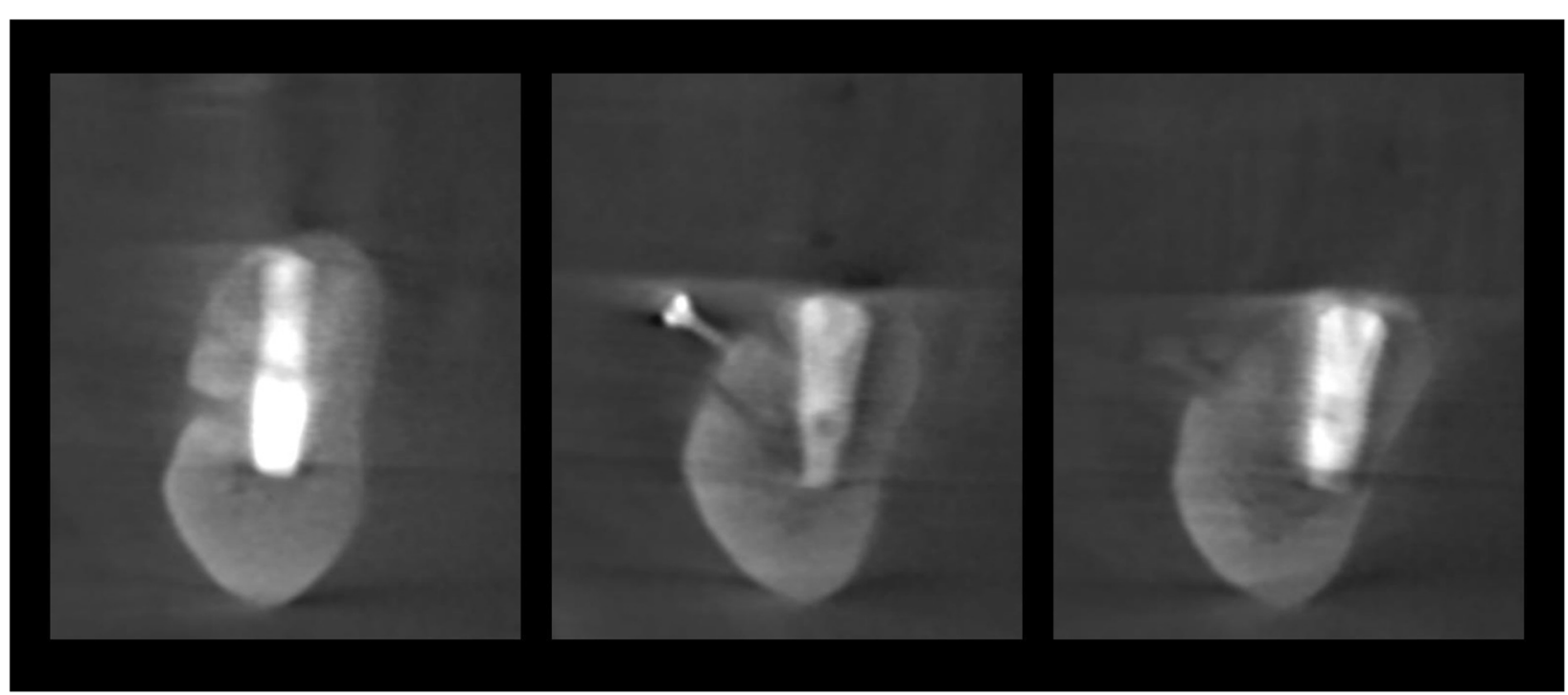

Fig. 7 A CT scan after surgery

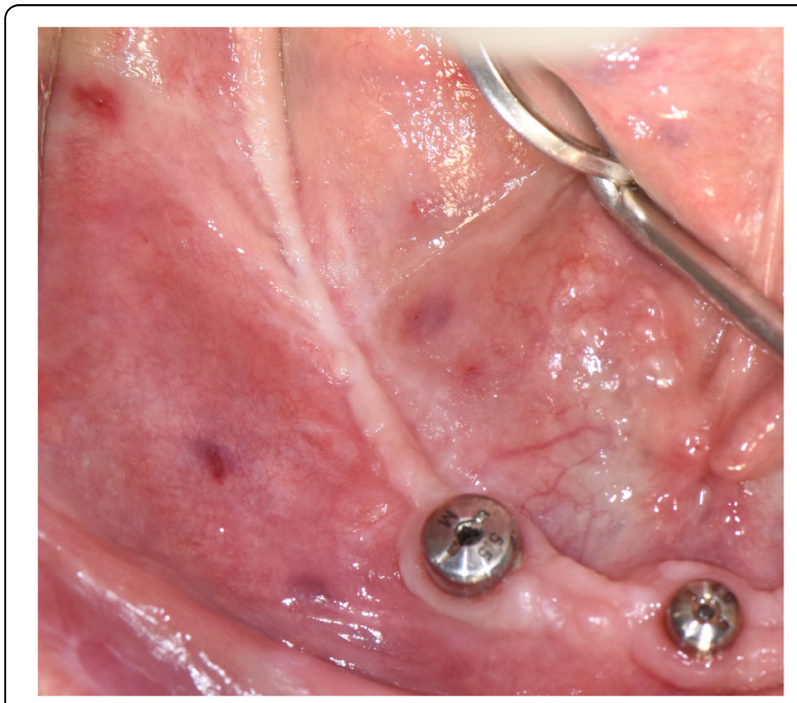

Fig. 8 Narrow band of keratinised gingiva at the second-stage surgery

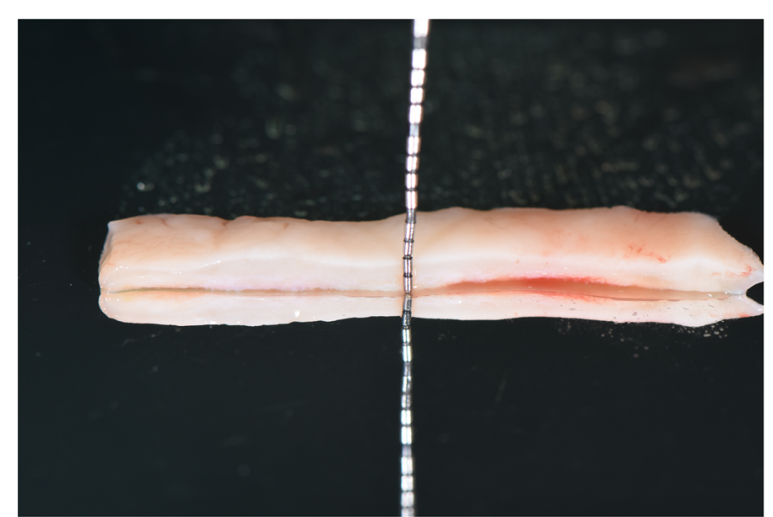

Fig. 9 A free gingival graft is obtained from the palate 


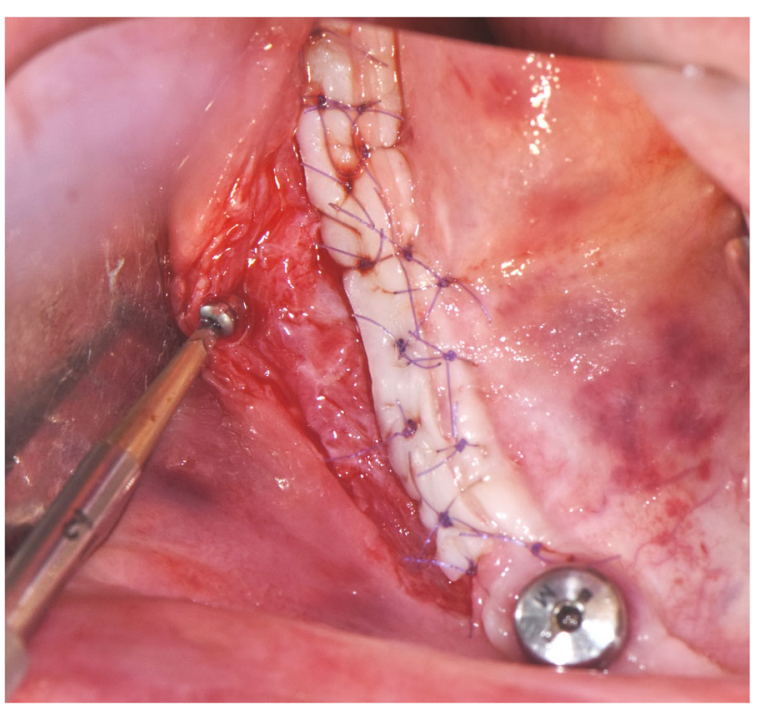

Fig. 10 Vestibuloplasty with free gingival graft is performed. Notice the titanium mini-screw that indicates the neurovascular bundle's position

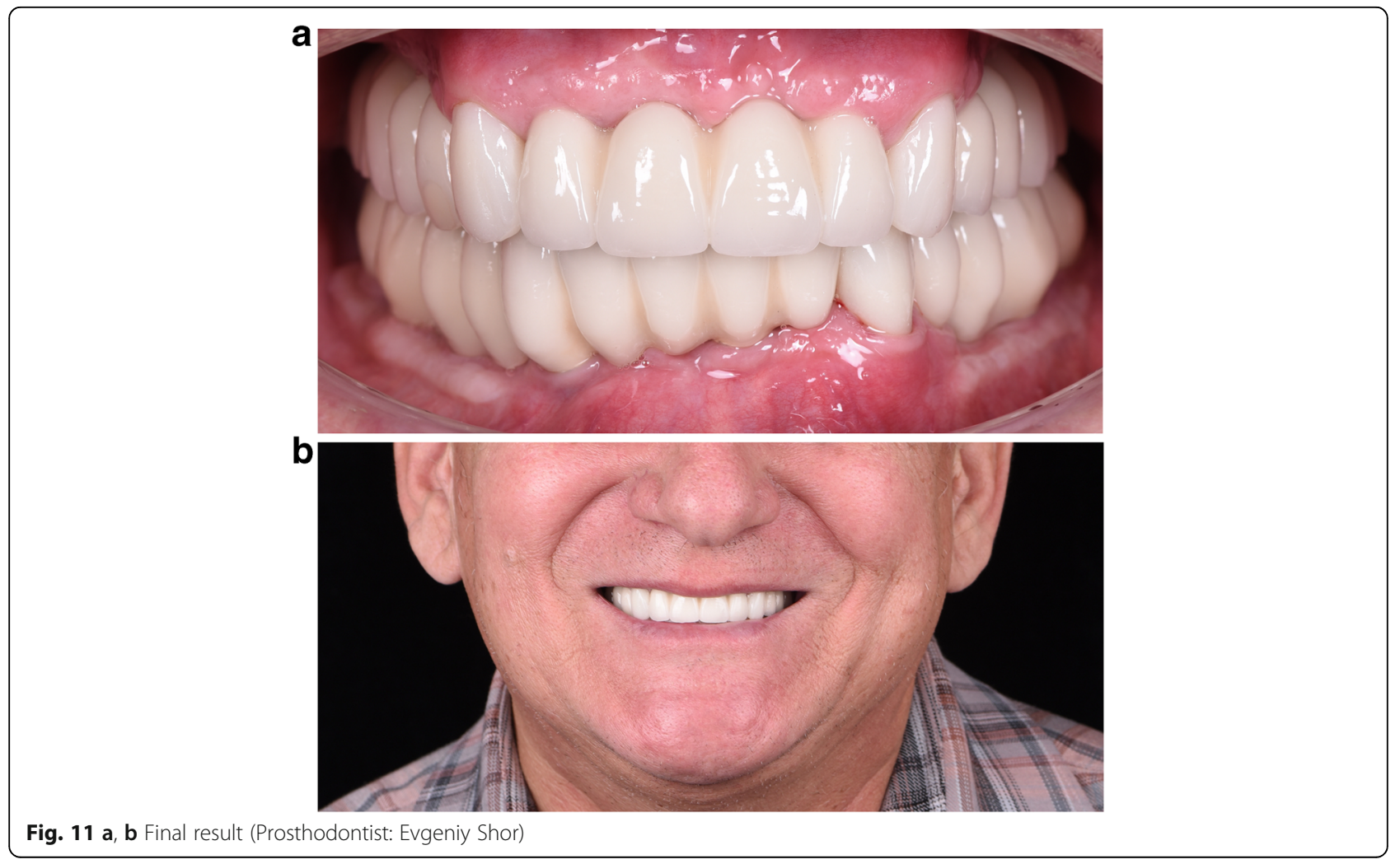




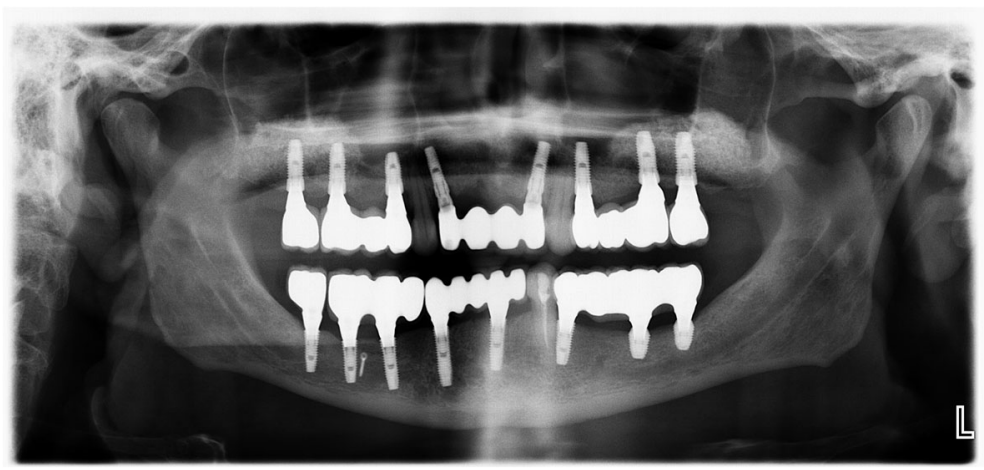

Fig. 12 A panoramic radiography after the delivery of the final prosthesis

A titanium mini-screw is then placed halfway in the lateral side of the mandible at the upper osteotomy line (Fig. 5). The screws offer two benefits: they serve as a passive barrier to the IAN and prevent it from migrating and the screws indicate the IAN's new location in radiological studies for identification during re-entry surgery (Figs. 6, 7). The titanium screws provide a convenient landmark for a clinician, minimising risks of IAN damage during the placement of healing abutments and/or vestibuloplasty (Figs. 8, 9, 10, 11, 12).

The space between the implants and repositioned neurovascular bundle is grafted, and the mucoperiosteal flaps are repositioned and sutured with resorbable sutures. Six months of healing time is allowed before second-stage surgery.

This technique was successfully implemented in 15 consecutive cases.

\section{Abbreviations}

IAN: Inferior alveolar nerve; IV sedation: Intravenous sedation

\section{Acknowledgements}

Not applicable

\section{Authors' contributions}

GD: performed literature search, analysed the data, wrote the manuscript. SG: conceived of the presented idea, wrote the manuscript, final approval. The author(s) read and approved the final manuscript.

\section{Funding}

Not applicable

Availability of data and materials

Not applicable

Ethics approval and consent to participate

Ethical approval is not required.

\section{Consent for publication}

Not applicable

\section{Competing interests}

George Deryabin and Simonas Grybauskas declare that they have no competing interests.
Author details

${ }^{1}$ Chicago, USA. ${ }^{2}$ S'OS Orthognathic Surgery, Vytenio 22-201, Vilnius, Lithuania.

Received: 2 August 2020 Accepted: 17 September 2020

Published online: 18 November 2020

References

1. Cawood JI, Howell RA. Reconstructive preprosthetic surgery. I. Anatomical considerations. Int J Oral Maxillofac Surg. 1991;20(2):75-82.

2. Zarb GA, Schmitt A. The longitudinal clinical effectiveness of osseointegrated dental implants: the Toronto study. Part III: Problems and complications encountered. J Prosthet Dent. 1990 Aug;64(2):185-94.

3. Rosenquist BE. Fixture placement posterior to the mental foramen with transpositioning of the inferior alveolar nerve. Int J Oral Maxillofac Implants. 1992:7(1):45-50

4. Babbush CA. Transpositioning and repositioning the inferior alveolar and mental nerves in conjunction with endosteal implant reconstruction. Periodontol 2000. 1998;17(1):183-90.

\section{Publisher's Note}

Springer Nature remains neutral with regard to jurisdictional claims in published maps and institutional affiliations.

\section{Submit your manuscript to a SpringerOpen ${ }^{\circ}$ journal and benefit from:}

- Convenient online submission

- Rigorous peer review

- Open access: articles freely available online

- High visibility within the field

- Retaining the copyright to your article

Submit your next manuscript at $\boldsymbol{\nabla}$ springeropen.com 